\title{
Why CALL Why Not MALL: An In-depth Review of Text-message Vocabulary Learning
}

\author{
Ali Derakhshan \\ Allameh Tabataba'i University, Tehran, Iran \\ Email: aderakhshanh@gmail.com \\ Hossein Khodabakhshzadeh \\ English Department, Islamic Azad University, Torbat-e-Heidarieh branch, Torbat-e-Heidarieh, Iran \\ Email: hkhodabakhshzade@gmail.com
}

\begin{abstract}
Vocabulary learning has gained a profound ground in language learning, and with the advent of text-messaging, researchers have shown great enthusiasm to investigate the interplay between the two. Therefore, the present paper seeks to firstly define MALL (Mobile Assisted Language Learning) in terms of language learning, to secondly compare and contrast E-learning and M-learning, to thirdly elaborate upon theories underlying MALL in general and text-message vocabulary learning in particular, to fourthly explicate the practical studies done on text-message vocabulary learning, and finally to enumerate the advantages and disadvantages of MALL and text-message vocabulary learning.
\end{abstract}

Index Terms-vocabulary learning, mobile-assisted language learning, E-learning, incidental vocabulary learning, spacing effect, constructivism

\section{INTRODUCTION}

Vocabulary is considered one of essential components of a language. Laufer (1998) and Nation (1990) believe that if students of English as a Foreign Language want to understand non-specialized English texts, they need to learn 5000 base words which are considered just a minimal requirement. This means that learners should purposefully practice or rehearse the words to facilitate long term retention (Genesee, 2000; Hulstijn, 2001). However, in many educational and academic milieus around the world, the amount of class time is limited. In Iranian universities, for example, a typical class meets once a week for 90 minutes. This problem urges teachers and researchers to make difficult choices about how to use that limited time to promote language learning. Since foreign language students usually have limited opportunities to speak and hear the target language only in the classroom, it makes sense to draw on other kinds of practice and exposure. Given the centrality of lexical knowledge to learning a language, research into the effectiveness of various types of vocabulary learning methods as well as instructional techniques has been of considerable value to second language research and pedagogy. One such way is through an interaction which allows students to use language and teachers to give feedback via text-message. Vocabulary learning via text-message is one of the emerging areas in communication (Andrews, 2003; Norbrook \& Scot, 2003; Thornton \& Houser, 2002; 2003; 2005; McNicol, 2005; Levy \& Kennedy, 2005; 2008; Collins, 2005; Chinnery, 2006, Pecherzewska \& Knot, 2007; Lu,2008; and Chen \& Chung, 2008). Text-messaging can be applied in language teaching and learning as a complementary teaching aid since vocabulary gains can be fostered by its portability, immediacy, novelty, motivation, and the spacing effect it generates (Thornton \& Houser, 2005). The text-messaging vocabulary learning is likely to provide several of the optimal psychological conditions for the effectiveness of any vocabulary activity described by Nation (2001). First, cumulative learning is the most effective way of learning vocabulary; learners are more capable of dealing with a limited amount of information at a time, so too much information may confuse them or de-motivate them. Second, motivation and interest are the important enabling conditions for noticing which is the first step in learning. Nation(2001) states that the third psychological condition for vocabulary learning is that text-message vocabulary learning offers a novel and portable learning experience as well as a relaxing condition; therefore, learners can study the words almost at anytime and anywhere. Also, student-initiated use of language supported by teachers can foster vocabulary learning by increasing the 'Cognitive Involvement Load' (Hulstijn \& Laufer, 2001, p. 542) through 'Spacing Effect' (Greene, 1989; Wozniak 1995; Dempster, 1996; Seabrook, Brown, \& Solity, 2005). By using the word to make a sentence, sending it at spaced intervals to teachers via text-message, and receiving the feedback learners can build a net of well-connected and wellpracticed paths and thus retrieve the target word more easily. Furthermore, constructivism, learner-centeredness, situated learning, immediacy, flexibility, portability, context sensitivity, social interactivity, connectivity, individuality and informal learning play key roles in learning words via text-messaging (Lu, 2008; Crowe \& van't Hooft, 2006; Klopfer, Squire, \& Jenkins, 2002; Kukulska-Hulme, 2007). 
Vocabulary is one of the indispensable components of a language (Adolphs \& Schmitt, 2003; Nation, 2001; Hulstijn \& Laufer, 2001; Laufer \& Goldstein, 2004; Laufer et al. 2004; Gu, 2003; Huang, 2007). L2 learners are aware of the extent to which limitations in their vocabulary knowledge restrict their communication skills (Nation, 2001). Consequently, one of the main obstacles that L2 learners encounter in their endeavor of learning vocabulary is the number of words they need to acquire in order to become fluent in their L2. Teachers may well understand this need but may not know how to support their students in this endeavor. Therefore, from a pedagogical perspective, there is a need for research that helps to find out learning tasks that provide opportunities for L2 vocabulary learning. Limited amount of class time necessitates utilizing text-messaging vocabulary learning in our pedagogical milieu.

\section{MOBILE LEARNING}

Mobile learning has been evolving rapidly. Pettit \& Kukulska-Hulme (2007) postulate that early generations of mobile learning projects inclined to propose formally-designed activities, carefully crafted by educators and technologists, and using emerging technologies that were not yet widely accessible or well understood. Current widespread ownership of mobile devices mean that learners have strong tendency to take the lead and engage in activities which are motivated by their personal needs and circumstances of use, including those activities which arise from greater mobility and travel (Kukulska-Hulme, Traxler \& Pettit,2007; Pettit \& Kukulska-Hulme, 2007). Whereas in the past, mobile learning has often been defined in terms of its use of mobile technologies, more recent conceptions of MALL primarily focus on the mobility of the learner (Sharples, 2006). The informal aspects of m-learning are also emphasized (e.g. Fallakhair, Pemberton \& Griffiths, 2007). Although Pettit \& Kukulska-Hulme (2007) argue that mlearning involves the use of any portable learning materials including books, audio-cassettes, audio-CDs, and portable radios and DVD players, m-learning usually concentrates on the most recent technologies. Trifanova et al. (2004 p.3) define mobile devices as "any device that is small, autonomous and unobtrusive enough to accompany us in every moment". Typically, m-learning is identified (Geddes, 2004) by the tools used. On par with others, Traxler (2005 propounds that mobile learning can perhaps be defined as any educational provision where the sole or dominant technologies are handheld or palmtop devices.

However, the latest definitions of mobile learning focus on the learner rather than on the technology (Winters, 2006; Naismith et al., 2004). An accepted definition of mobile learning is "any sort of learning that happens when the learner is not at a fixed, predetermined location, or learning that happens when the learner takes advantage of learning opportunities offered by mobile technologies" (O'Malley et al.,2003). Vavoula and Sharples (2002 ) (in Naismith et al., 2004) state that since learning takes place over time and space and in different areas of our lives, mobility is highly regarded as one essential part of learning. Winters (2006) believe that although there is a consensus that mobile technologies are just one of the means through which learning is mediated, they seem to offer unique affordances (Klopfer, Squire \& Jenkins, 2002) which could be very useful to facilitate learning. There is no doubt that "mobile devices have opened up a vast range of possibilities for learning in ways that are convenient and suited to the needs of an individual within the context of their lifestyle" (Kukulska-Hulme, 2006, p. 128).

Chinnery (2006) believes that as in any other technology-enhanced language learning paradigms, mobile learning environments might be face-to-face, distance, or online. Colpaert (2004) emphasizes before deciding on the role of mobile technologies, we need to consider the importance of developing the language learning environment; he further emphasizes that learners should be well-prepared before the technologies open up their ways into our academic lives. Alternatively, Salaberry (2001) contends against technology-driven pedagogy proposing that despite their revolutionary status, it is not clear that any modern technology has offered the same pedagogical benefits as traditional second language instruction. Furthermore, teachers need to be concerned about investing time and money in unproven technology.

Chinnery (2006) explicates that regardless of these and other unstated stipulations, technologies, mobile or otherwise, can be instrumental in language instruction. These technologies are not in and of themselves instructors; rather, they are instructional tools which work as adjunct in the process of teaching and learning, and the effective use of any tool in language learning requires the thoughtful application of second language pedagogy.

Many of the studies addressing content-related MALL activities appear to subscribe to a model whereby materials are delivered to learners via text-messaging or a website. Very few activities, however, support learner collaboration or communication. While Dias (2002a; 2002b) promotes learner-learner interaction, of the work using more expensive mobile devices, only JISC (Joint Information Systems Committee) (2005) draws on MALL to reinforce collaboration and co-construction of knowledge; learners had to find information and share it with their peers so as to create an overall understanding of a real-world problem, namely, the layout of the campus and the location and purpose of various buildings. Kukulska-Hulme \& Shield (2007) argue that although MALL activities are grounded on the assumptions of mobility and portability, they seem not to be fully exploited in the design of MALL activities, for example, while it could be argued that sending vocabulary items and quizzes to learners via text-messaging draws on the mobility of the device, it could equally well be argued that such messages could be sent to SMS-enabled landlines or to wireless-enabled computers. Many of the studies also ignored the 'anytime, anywhere' affordances supposedly offered by mobile devices; for example, text-messages were sent to learners at set times, on set days (Levy \& Kennedy, 2005; 2008; Lu, 2008) rather than learners being able to obtain this information as and when they wanted it. The present 
researchers, however, postulate that in order to get over this shortcoming we need to send students text-messages not at fixed times.

Movement from E-learning to M-Learning: It is a long-time project that aims to create a learning environment for wireless technologies by developing course materials for range of mobile devices (Colazzo et al., 2003). Laouris \& Eteokleous (2005) made some comparisons between e-learning and m-learning, and they try to foresee the future of $\mathrm{m}$ learning and the methods and technologies that should be used for successful m-learning.

Similarly, Mostakhdemin-Hosseini \& Tuimala, (2005) believe that mobile learning can be considered as a natural evolution of e-learning, completing a missing component of the solution (i.e. adding the wireless feature). The transition from the e-learning to m-learning can be argued and identified by a change of terminology. For example, the dominant terms in the e-learning era were: multimedia, interactive, hyperlinked, media-rich environment (Laouris \& Eteokleous, 2005). In the m-learning milieu, Laouris \& Eteokleous (2005) assert terms such as intimate, situated, informal, connected, lightweight, private, spontaneous, and personal to characterize the context. While Table 1 compares and contrasts the choice of terminology with underlying characteristics of the two types of learning environments, Table 2 demonstrates their differences in the context of pedagogy and environment.

Table 3 represents the differences between e- and m-learning environments with respect to modes of communication. While e-learning was compatible with the classroom paradigm, m-learning calls for environment- and time independent pedagogy (Laouris \& Eteokleous, 2005).

TABLE 1

TERMINOLOGY COMPARISONS BETWEEN E-AND M-LEARNING

\begin{tabular}{ll}
\hline e-learning & m-learning \\
\hline Computer & Mobile \\
\hline Bandwidth & GPRS, Bluetooth \\
\hline Multimedia & Objects \\
\hline Interactive & Spontaneous \\
\hline Hyperlinked & Connected \\
\hline Collaborative & Networked \\
\hline Media-rich & Lightweight \\
\hline Distance learning & Situated learning \\
\hline More formal & Informal \\
\hline Simulated situation & Realistic situation \\
\hline hyper learning & Constructivism, \\
& collaborative \\
\hline
\end{tabular}

Taken from Laouris \& Eteokleous (2005)

TABLE 2

PEDAGOGICAL DIFFERENCES BETWEEN E-AND M-LEARNING ENVIRONMENTS

\begin{tabular}{ll}
\hline $\begin{array}{l}\text { More text- and graphics based } \\
\text { instructions }\end{array}$ & $\begin{array}{l}\text { More voice, graphics and animation based } \\
\text { Instructions }\end{array}$ \\
\hline Lecture in classroom or in internet labs & Learning occurring in the field or while mobile \\
\hline
\end{tabular}

(Taken from Laouris \& Eteokleous, 2005)

TABLE 3

DIFFERENCES BETWEEN E- AND M-LEARNING ENVIRONMENTS WITH RESPECT TO MODES OF COMMUNICATION A) INSTRUCTOR TO STUDENT COMMUNICATION

\begin{tabular}{lc}
\hline Time-delayed & A) INSTRUCTOR TO STUDENT COMMUNICATION \\
\hline Passive communication & Instant communication \\
\hline Asynchronous & Synchronous \\
\hline Scheduled & Spontaneous \\
\hline & \\
\hline Face- to- face & B) STUDENT TO STUDENT CoMMUNICATION \\
\hline Audio-teleconference common & Flexible \\
\hline Private location & Audio- and video- teleconference possible \\
\hline Travel time to reach to internet site & No geographic boundaries \\
\hline & No travel time \\
\hline
\end{tabular}

\section{EXPECTATIONS FOR AND BARRIERS TO MOBILE PHONE LEARNING}

Stockwell (2008) argues that research into mobile phone learning represents a paradox. On the one hand, there are teachers and researchers who are ardent about using mobile technologies, believing that providing means for learners to study "anytime, anywhere" boosts more frequent and integral use of learning technologies as opposed to the more occasional use generally associated with computer laboratories (Roschelle, 2003). Many teachers and researchers see mobile learning as a promising area of learning, one that is to be enthusiastically welcomed by the learners using technologies that most already possess. Others take a more mediocre approach, such as Levy and Kennedy (2005), who 
argue that the widespread acceptance of communication technologies in non-learning contexts does not necessarily mean that they will be effective or valued in educational contexts.

On the other hand, there are some other teachers and researchers who are in favor of a more pessimistic approach, pointing out many factors that impede their introduction into language learning environments (Stockwell, 2008). Wang and Higgins (2006), for example, give a comprehensive overview of the psychological, pedagogical, and technical barriers to using mobile phones in the classroom. They argue that it is time-consuming for the learners to embrace new technologies, and it is not logical to expect all learners to feel comfortable with using new technologies at the same rate. Dias (2002a) persuasively argues that some learners may just see mobile learning as an intrusion into their own personal space, and this in turn would constrain the degree of their acceptance. From a pedagogical pint of view, KukulskaHulme and Shield (2007) argue that activities that capitalize on mobility and portability which are considered as the very rationale for using mobile technologies are not as commonplace as one might hope, and although the "anywhere" factor is often not an issue, the "anytime" part is, where learners are sent messages by email or text-messaging at either fixed times, or times that suit the teacher, a tendency which seems to defeat the purpose of using mobile technologies at all. Thornton \& Houser (2002), however, experienced the technical limitations including the size of the screen and the difficulties of inputting text, particularly English.

\section{INCIDENTAL VS. INTENTIONAL VOCABULARY LEARNING}

Vocabulary learning is prominent for English learning because vocabulary constitutes the basic building blocks of English sentences (Nation, 2001). Research into vocabulary learning for English as a foreign language (EFL) student has played a prominent role. Many research findings reveal that poor knowledge of vocabulary frequently leads to incorrect inferences or misunderstanding of the content when reading English materials (Laufer, 2001; 1998; Gu, 2003; Huang, 2007; Nation, 2001). Mobile devices have been increasingly developed, designed and utilized to 'ultimately support a lifetime of personal and social enrichment' that can support education in general (Roschelle, Sharples \& Chan, 2005,p.161) and vocabulary learning in particular(Andrews, 2003; Thornton \& Houser, 2002; 2003, and 2005; Levy \& Kennedy, 2005; 2008; Lu,2008; Chen \& Chung, 2008).

Vocabulary learning activities generally fall into two types: intentional and incidental learning of vocabulary (Hulstijn 2001; Nation, 2001). Incidental vocabulary acquisition is generally defined as the learning of vocabulary as the by-product of any activity not explicitly geared to vocabulary learning and is contrasted with intentional vocabulary learning, defined as any activity geared at committing lexical information to memory (Hulstijn, 2001). The intentional vocabulary learning refers to activities that aim at vocabulary development predominantly in which learners need to pay attention to the words they want to learn. When vocabulary is learned predominantly through extensive reading, with the student guessing at the meaning of unknown words, the activities are called incidental learning of vocabulary (Robinson, 2005; Huckin \& Coady, 1999; Nakata, 2008). Huckin \& Coady (1999) believe that incidental learning provides opportunities for inferring word meaning in context, which later enables vocabulary acquisition and reading at the same time and is more individualized and student-oriented because the vocabulary being acquired is dependent on the student's own selection of reading materials. Huang (2007), however, argued that incidental learning of vocabulary may lead to such problems as incorrect inferences, and lack of retention. Huckin \& Coady (1999) cogently argue that the problem lies in the fact that correct inference of word meanings is dependent on the comprehension of $95-98 \%$ of the words in the text. According to Laufer's survey (1992), the reader's understanding of 95\% of familiar words and $2 \%$ of unfamiliar words is necessary for text comprehension. In a similar line of inquiry, Shahrzad \& Derakhshan (2011) investigate the effect of instruction in deriving word meaning on incidental vocabulary learning. They concluded that inferring word meaning based upon some strategies would lead to incidental vocabulary learning.

Therefore, any learning, whether intentional or incidental, can only take place with some degree of attention (Schmidt, 1994). By the same token, Hulstijn (2001) claims that intentional or incidental learning requires some attention and noticing. However, attention is deliberately directed at committing new information to memory in the case of the former whereas the involvement of attention is not deliberately geared to an articulated learning goal in the case of the latter. Most scholars agree that except for the first few thousand most common words, L2 vocabulary is predominantly acquired incidentally (Huckin \& Coady 1999).

A general problem with the operational definition of incidental vocabulary acquisition is that it seems to suggest that incidental learning occur unconsciously. Gass (1999) notes that defining incidental vocabulary acquisition as the 'sideeffect' of another activity neglects the active role of the learner in this process. The fact that incidental learning occurs as a by-product of reading does not automatically imply that it does not involve any conscious processes (Rieder, 2003).

Huckin \& Coady (1999) point out that incidental vocabulary learning has certain advantages over intentional vocabulary learning, including the following: (a) It is contextualized, giving the learner a richer sense of a word's use and meaning than can be provided in traditional paired-associate exercises, (b) it is pedagogically efficient in that it enables two activities - vocabulary acquisition and reading - to occur at the same time, and (c) it is more individualized and learner-based because the vocabulary being acquired is dependent on the learner's own selection of reading materials.

MALL and Incidental Vocabulary Learning 
In recent years, studies on mobile technology assisted vocabulary learning are increasing( Andrews, 2003; Norbrook \& Scot, 2003; Thornton \& Houser, 2002; 2003, and 2005; McNicol, 2005; Levy \& Kennedy, 2005; 2008; Collins, 2005; Chinnery, 2006, Pecherzewska \& Knot, 2007; Lu,2008; Chen \& Chung, 2008). These studies tend to draw on unique characteristics of immediacy, flexibility, portability, context sensitivity, social interactivity, connectivity and individuality (Lu, 2008; Crowe \& van't Hooft, 2006; Klopfer, Squire, \& Jenkins, 2002; Kukulska-Hulme, 2007). These studies have mainly concentrated on strengthening students' vocabulary learning in an environment where students use mobile technologies for prescribed vocabulary learning tasks, or tested designed personalized learning systems to enhance students' vocabulary learning in the short term in language related courses (Chen \& Chung, 2008;Song \& Fox, 2008; Stockwell, 2007;2008; Thornton \& Houser, 2005).

\section{SLA THEORIES \& MALL}

Unlike stagnant computer instruments and devices, mobile devices and mobile phones are portable, socially interactive, context sensitive, connective and individual to language learners (Klopfer et al., 2002). It can be argued that learners are able to access learning materials and to communicate with their teacher and peers with fewer time and space constraints (Chinnery, 2006; Nah, 2008). Therefore, MALL activities contribute to the provision of comprehensible input, negotiation of meaning, and comprehensible output. These properties of mobile phones, for example, can provide language learners with comprehensible input through pre-programmed software, via Internet searching, and through dialogue with their teacher or peers (Nah, White, \& Sussex, 2008). These characteristics provide opportunities for negotiation of meaning, by letting language learners interact and negotiate with language learning software containing pre-programmed responses, and with real persons such as language teachers, peers and language experts. Furthermore, these properties can boost the learners to produce comprehensible output by writing, selecting or oral reporting based on what they have learned. They are able to respond directly from their WAP site, send mobile email or text-message, or make a call at anytime, anywhere, especially in self-access and self-selected situations outside the normal classroom. Mobile learning environment can foster collaborative and student-centered learning (Savill-Smith \& Kent, 2003; Wood, 2003; Comas-Quinn, Mardomingo, \&Valentine, 2009) because of the advantages of mobile devices. Encouragement, support and guidance contribute to collaborative learning which is initiated by peers and teachers using synchronous and asynchronous communication tools including SMS, mobile email, mobile discussion boards, and mobile messengers (Nah, White, \& Sussex, 2008). These communication tools have the potentiality to contribute to student-centered learning, and to obtain customized help and information on time and through personalized learning environments where language learners can control their learning time, pace and level (Nah, White, \& Sussex, 2008)

Over the past few decades, a growing body of SLA theories and approaches have been hypothesized, formulated and utilized for second language learning (Ellis, 2008). Input, interaction, output and sociocultural theories, as well as the constructivist, learner-centered/activity-centered learning, situated leaning, and collaborative learning shed light on the rationale of the MALL studies since they have been widely used in computer-assisted language learning (CALL) research(Nah, 2008); hence, they have all found their ways to concentrate on MALL as an offspring of CALL.

\section{A. Constructivism}

John Dewey (1938) is an advocate of experiential learning which lends itself well to constructivism. Dewey maintains that learners need to experience, feel, sense the real world concepts and ideas and relate them to their own existing knowledge and schemata in order to construct meaning. Learners cannot simply memorize, absorb or copy prepackaged ideas but must construct their own versions through actively engaging in personal experimentation. Two major schools of thought have appeared in constructivist thinking. Cognitive constructivism, which is based on the work of Jean Piaget (1970), emphasizes the mental processes involved in the individual's construction of knowledge. Social constructivism, on the other hand, according to the theories of Lev Vygotsky (1978), concentrates on the social and historical contexts that are responsible for the construction and creation of knowledge. Vygotsky highlights that individuals cannot detach themselves from the sociopolitical contexts in which they live, and that language and culture are extricably bound together and inevitably construct their interpretation of reality. This concept is particularly relevant in language learning as the native language and culture, used as "frameworks through which humans experience, communicate and understand reality" (Simina \& Hamel, 2005), are used to make sense of the target language and culture. In a similar line of inquiry, Felix (2005) recommends that both the cognitive and the social aspects of constructivist should receive parallel and equal importance. Knowledge is constructed individually but mediated socially" (Felix, 2005, p. 86).

Comas-Quinn, Mardomingo, \&Valentine (2009) strongly highlight that sharing, collaboration and interaction with other peers and experts from whom the learner can obtain different perspectives on the problem clearly reinforce the opportunities for learning. Since computer and mobile technologies broaden the possibilities for interaction with other learners, which is of prime importance in language learning, they are ideally suited to support a social constructivist approach to task and course design.

Constructivist paradigm in language learning attempts to inform course design. It also tries to broaden previous approaches such as behaviorist rote learning or the cognitive approach that underlies the widely used communicative 
system. It is now well appreciated that neither the sole acquisition of grammar and vocabulary nor their controlled use in communicative situations are adequate to achieve language proficiency (Comas-Quinn, Mardomingo, \&Valentine, 2009). Levy \& Kennedy (2005; 2008) maintain that if language learners want to be successful, they also need to be able to access information, process it and use it in real situations. Mobile devices in general and text-messaging in particular have the potentiality and flexibility to enable learners to carry out these processes in a personalized manner.

\section{B. Spacing Effect}

Spacing effect is believed to have a role in vocabulary learning via text-messaging. Based on research on memory and learning, for an item to be stored in long-term memory distributed practice is superior to massed practice (Wozniak, 1995; Dempster, 1996; Seabrook, Brown, \& Solity, 2005; Serrano \& Munoz, 2007). Study conditions in which repetitions of items to be acquired or learned appear in spaced or distributed sequences have been found to lend themselves better for subsequent retention than presentations in which repetitions occur quickly (Braun and Rubin, 1998; Cuddy and Jacoby, 1982; Dempster, 1987; Greene, 1989; Hintz-man, 1976; Melton, 1970; Russo et al., 2002; Seabrook, Brown \& Solity, 2005; Toppino and Bloom, 2002; Serrano \& Munoz 2007). This phenomenon has been known as the spacing effect which further argues that memory for items which are presented and then immediately repeated, i.e. , massed practice, is worse than for items which are repeated after some intervening items have appeared, i.e., distributed practice. In other words, cognitive psychologists have found that when two presentations of a stimulus are close together, that is, massed presentation, then the improvement in memory performance, compared with a single presentation, is limited. On the other hand, when two presentations of a stimulus are temporally farther apart, that is, spaced presentation, then performance on a memory test is significantly better than performance after a single presentation. The advantage in memory performance that occurs when two presentations are spaced instead of massed is referred to as the spacing effect (Greene, 1989).

To provide more evidence for the adequacy and impact of spacing effect, Challis (1993) maintains that spacing effect is also present in both intentional and incidental learning. This suggests that students of a foreign language should review words at spaced intervals and in a variety of contexts to facilitate long-term memory storage. However, it appears that little has been done about vocabulary learning via technology. So, the present researchers postulate that through sending and receiving text-messages at spaced interval, students would be able to retain words for a longer period of time. Distributed presentations of words result in better memory for those words than do clustered presentations. This conception, therefore, led to the expectation that in a classroom setting, many short teaching sessions would produce better learning than fewer, longer sessions.

To provide evidence for the practical and pedagogical aspects of spacing effect, Traxler (2007, p.8) puts a great emphasis on the fact that "mobile learning allows students to take advantage of small amounts of time and space for learning". While Traxler referred to distance-learning and part-time students who need to make use of every available moment. For instance, in the Australian context, where virtually all university students have mobile phones and use them for text messaging every day ,text-messaging presents itself as a technology that can be exploited to support such practice free of any "usability issues" (Kukulska-Hulme, 2007).

\section{MALL in All StAgES OF LEARNING PROCESS}

Apart from these underlying theories which support using MALL devices and text-message vocabulary learning, Stead (2005) believes that m-learning seems to have a place at all stages of the accepted learning process.

a) Engage: The original m-learning project focused on the engagement of reluctant learners. The novelty and status of the devices, as well as the visual and auditory appeal of the materials seem to be key factors (Stead, 2005).

b) Assess: Using m-learning to assess skills has several advantages:

- You can use the devices privately and in your own time.

- M-learning assessment is less threatening than paper-based screeners and initial assessments for new learners.

- M-learning is not as frightening as computer-based assessment.

c) Teach: M-learning uses innovative and developing technologies. It is clear that m-learning has a role in assessment and in practice. There is some evidence that being able to look at learning as many times as possible might be the ideal way for some learners to understand a concept.

d) Practice: Since material is accessible on learner's phone, he or she is in a better position to practice the material. Whenever learners have a spare five minutes, they can use it to practice some learning.

e) Assess: Formative assessment can be carried out using mobile technology, privately and independently.

\section{STUDIES ON MALL}

Once the theoretical aspects of vocabulary learning have been dealt with, the practical aspects of the issue will be chronicled. One of the first projects using mobile phones in language learning was developed by the Stanford learning lab, which explored their use in language learning (Brown, 2001). They developed Spanish study programs utilizing both voice and text-messages with mobile phones. After registration, the students were automatically separated in 5 different groups. One group received announcements via e-mail, other 3 groups via text-messaging (but different 
interaction was necessary in every group) and the last - via web. These programs included vocabulary practice, quizzes, and word phrase translations, and access to live talking tutors. The conclusions of the experiment were that the students in certain scenarios preferred SMS as a medium to e-mail or web-based announces. For example, mobile phones were effective for quiz delivery if delivered in small chunks; it was also found that automated voice vocabulary lessons and quizzes had great potential to enhance vocabulary learning. In this experiment, students' attitudes were also taken into account. While some of the participants were satisfied with this new mode of enhancing their command of English, others believed that vocabulary learning via SMS had some advantages and disadvantages; they believed that convenient small question chunks to test knowledge during opportunistic bit of time was a great advantage. However, they assumed that small screen was difficult to focus on while outdoors; also small bits of text do not provide enough experience for learning new content. In a nutshell, participants considered learning words via text-messaging as a beneficial extracurricular activity.

Kennedy and Levy (2008) were successful in their experiment conducted in (2005) with the third-year students who were a small group of highly motivated learners who had already invested considerable time and energy in their Italian study, so they decided to test the applicability of SMS also in first-year courses for complete beginners. They note that freshmen's motivation is always higher than that of third year. The pre-trial survey in their study showed that about one third of respondents had used their mobile phones for study-related purposes previously, but such use had been limited to exchanging SMSs with fellow students regarding assessment tasks or using diary functions. Overall, the post-trial survey showed that the vast majority of the students had found the experience a positive one. While $84 \%$ said they had enjoyed receiving the messages, most had also found them useful, as they agreed that the messages had helped consolidate their vocabulary $(87.3 \%)$, extend their vocabulary $(82.5 \%)$, and develop their interest in Italian vocabulary $(80.7 \%)$, a smaller majority felt the messages had helped consolidate their knowledge of grammar $(78.6 \%)$.

In a similar line of inquiry, Thornton and Houser $(2002 ; 2003 ; 2005)$ developed several projects using mobile phones to explore the effectiveness of learning via mobile phone on Japanese college students' vocabulary gains. In their 2005 study, three times a day, they sent short mini-lessons to students $(\mathrm{N}=13)$, in discrete chunks so as to be easily readable on the tiny screens. Lessons defined five words per week, recycled previous vocabulary, and used the words in various contexts. Students were tested biweekly and compared to groups that received identical lessons via Web and on paper $(\mathrm{N}=13)$. The results indicated that the SMS students learned twice the number of vocabulary words as the Web students, and that SMS students proved their scores by nearly twice as much as students who had received their lessons on paper. The results of the second experiment showed that another mobile phone group $(\mathrm{N}=25)$ gained significantly more vocabulary than the group using paper materials $(\mathrm{N}=43)$. Thornton and Houser concluded that the regular messages sent by mobile phone could generate the spacing effect which facilitates vocabulary retrieval. To examine the extent of the spacing effect, a follow-up experiment using vocabulary lessons of different lengths was conducted. The long version contained a full context (two sentences paraphrasing the target word and three example sentences) whereas the short version listed only one paraphrasing sentence and one example sentence. No significant difference in vocabulary gains was found between learning from the longer and shorter lessons. Thornton and Houser mentioned that mobile phones enhanced regular study, which in turn, led to more exposure to the target words and more vocabulary gains than did the detailed presentation of the lessons. Their finding is in accordance with the empirical evidence in the cognitive psychological research that constant and distributed practice has a more beneficial effect on memory and learning than massed practice. Words are memorized significantly better when they are presented temporally apart than when they are presented together at one time (Dempster, 1987; Greene, 1989; Nation \& Meara, 2002). Majority of the students preferred the SMS instruction and wished to continue such lessons, and believed that it would be a valuable teaching method. The authors theorized that their lessons had been effective due to being delivered as push media which promote frequent rehearsal and spaced study, and utilized recycled vocabulary.

\section{CONCLUSION}

It is worth mentioning that MALL studies have gained prominence over the last few years. The present paper recapitulated the major concepts and theories underlying MALL. It also elaborated profoundly upon the differences between e-learning and m-learning. It then went on to illuminate the ways through which researches have integrated the text-message technology with vocabulary learning culminating in a complementary way of increasing their domain of vocabulary capitalizing upon "anywhere anytime" advantage of m-learning. It then summarized the practical studies done on text-message vocabulary learning. Finally, the paper ended up by enumerating the advantages and disadvantages of m-learning and text-messaging.

\section{REFERENCES}

[1] Adolphs, S. \& Schmitt, N. (2003). Lexical coverage of spoken discourse. Applied Linguistics, 24,425-38.

[2] Andrews, R. (2003). Lrn Welsh by Txt Msg. Retrieved 24th November 2007 from: http//news.bbc.co.uk/2/hi/uk_news/wales/2798701.stm.

[3] Braun, K., Rubin, D.C., (1998). The spacing effect depends on an encoding deficit, retrieval and time in working memory: evidence from once-presented words. Memory, 6 (1), 37-65. 
[4] Brown, E. (ed.) (2001). Mobile learning explorations at the Stanford learning lab. Speaking of Computers, 55. Stanford, CA: Board of Trustees of the Leland Junior University. Retrieved July 24, 2005, from http://sll.stanford.edu/projects/tomprof/newtomprof/postings/289.html

[5] Challis, B.H.(1993). Spacing effects on cued-memory tests depend on level of processing. Journal of Experimental Psychology, Learning, Memory, and Cognition, 19 (2), 389-396.

[6] Chen, C.-M. and Chung, C.-J. (2008). Personalized mobile English vocabulary learning system based on item response theory and learning memory cycle.Computers \& Education, 50(1), 77-90.

[7] Chinnery, M. G. (2006). Going to the MALL: Mobile Assisted Language Learning. Language Learning and Technlogy,1,9-16.

[8] Colazzo, L., Molinari, A., Ronchetti, M. \& Trifonova, A. (2003). Towards a multi-vendor Mobile Learning Management System. In Proc. ED- Media 2003., Honolulu, Hawaii, USA, 121-127.

[9] Colpaert, J. (2004). From courseware to coursewear? Computer Assisted Language Learning, 17(3-4), 261-266.

[10] Collins, T. (2005). English Class on the Air: Mobile language learning with cell phones. Proceedings of the Fifth IEEE International Conference on Advanced Learning Technologies (ICAL'05).

[11] Comas-Quinn, A., Mardomingo, R., \&Valentine, C. (2009). Mobile blogs in language learning: making the most of informal and situated learning opportunities. ReCALL, 21(1), 96-112.

[12] Crowe, A. and van't Hooft, M. (2006). Technology and the prospective teacher: Exploring the use of the TI-83 handheld devices in social studies education. Contemporary Issues in Technology and Teacher Education, 6(1), 99-119.

[13] Cuddy, L.J., Jacoby, L.L.(1982). When forgetting helps memory: an analysis of repetition effects. Journal of Verbal Learning and Verbal Behavior, 21, 451-457.

[14] Dempster, F.N. (1987). Effects of variable encoding and spaced presentations on vocabulary learning. Journal of Educational Psychology, 79, 162-170.

[15] Dempster, F.N.(1988).The spacing effect: a case study in the failure to apply the results of psychological research. American Psychologist, 43, 627-634.

[16] Dempster, F.N. (1996). Distributing and managing the conditions of encoding and practice. In Memory (Eds. E.L. Bjork \& R.A. Bjork), pp. 317-344. Boston: Academic Press.

[17] Dewey, J. (1938). Education and experience. New York: Simon and Schuster.

[18] Dias, J. (2002a). CELL phones in the classroom: Boon or bane? [Part 1] Calling Japan, 10(2), 16-22.

[19] Dias, J. (2002b). CELL phones in the classroom: Boon or bane? [Part 2] Calling Japan, 10(3), 8-14.

[20] Ellis, R.(2008). Studies in second language acquisition. Oxford: Oxford University Press.

[21] Felix, U. (2005). E-learning pedagogy in the third millennium: the need for combining social and cognitive constructivist approaches. ReCALL, 17(2), 85-100.

[22] Gass, S. (1999). "Discussion: Incidental vocabulary acquisition". Studies in Second Language Acquisition 21: 319-333.

[23] Geddes, S.J. (2004). Mobile learning in the $21^{\text {st }}$ century: benefit to learners. Accessed 27 th August 2007 from: http:/ knowledgetree. Flexiblelearning .net.au/edition06/download/geddes.pdf

[24] Genesee, F. (2000). Brain research: implications for second language learning. Eric Digest, December. Retrieved on June 1, 2003 from repositories.cdlib.org/crede/occrpts/eric_00_12_brain/

[25] Glenberg, A. (1979). Component-levels theory of the effects of spacing. Memory and Cognition, 7, 95-112.

[26] Greene, R.L. (1989). Spacing effects in memory: Evidence for a Two-process Account. Journal of Experimental Psychology: Learning, Memory and Cognition, 15, 371-377.

[27] Gu, Y. (2003). Fine brush and freehand: The vocabulary-learning art of two successful Chinese EFL learners. TESOL Quarterly, 37(1), 73-104.

[28] Horstmanshof, L. (2004). Using SMS as a way of providing connection and community for first year students. ASCILIITE Conference 2004, Perth, Western Australia.

[29] Huang, H.T. (2007). Vocabulary learning in an automated graded reading program. Language Learning \& Technology, 11(3), 64-82.

[30] Huckin, T. and Coady, J. (1999). Incidental vocabulary acquisition in a second language: A Review Studies in Second Language Acquisition, 21(2), 181-193.

[31] Hulstijn, J.H. (2001). Intentional and incidental second language vocabulary Learning: a Reappraisal of Elaboration, Rehearsal and Automaticity. In Cognition and Second Language Instruction (Ed. P. Robinson), pp. 258-286. Cambridge: Cambridge University Press.

[32] Hulstijn, J.H. \& Laufer B. (2001). Some empirical evidence for the involvement load hypothesis in vocabulary acquisition. Language Learning, 51,539-58.

[33] Jacoby, L.L. (1978). On interpreting the effects of repetition: solving a problem versus remembering a solution. Journal of Verbal Learning and Verbal Behavior, 17, 649-667.

[34] JISC (Joint Information Systems Committee) (2005). Multimedia learning with mobile phones. Innovative Practices with Elearning. Case Studies: Anytime, any place Learning. Accessed $27^{\text {th }}$ August 2007 from: http://www.jisc.ac.uk/uploaded_documents/southampton.pdf

[35] Kennedy, C. \& Levy, M. (2008). L'italiano al telefonino: Using SMS to support beginners' language learning. ReCALL, 20 (3), 315-330

[36] Kim, Y. J.(2008). The role of task-induced involvement and learner proficiency in L2 vocabulary acquisition. Language Learning, 58, 285-325

[37] Klopfer, E., Squire, K. and Jenkins, H. (2002). Environmental detectives: PDAs as a window into a virtual simulated world. Proceedings of IEEE International Workshop on Wireless and Mobile Technologies in Education. Vaxjo, Sweden: IEEE Computer Society, 95-98.

[38] Kukulska-Hulme, A. (2006). Learning activities on the move. Paper presented at the EUROCALL 2006 Virtual strand. http:// vsportal2006. googlepages.com/=KukulskaHulme_2006.pdf 
[39] Kukulska-Hulme, A. (2007). Mobile usability in educational contexts: What have we learnt? International Review of Research in Open and Distance Learning, 8(2),1-16.

[40] Kukuslka-Hulme, A. and Shield, L. (2007). An overview of mobile assisted language learning: Can mobile devices support collaborative practice in speaking and listening? Paper presented at the EUROCALL 2007 Virtual strand. http:// vsportal2007. googlepages.com/=KukulskaHulme_and_Shield_2007.pdf

[41] Kukulska-Hulme, A., Traxler, J. \& Pettit, J. (2007). 'Designed and user-generated activity in the mobile age', Journal of Learning Design, 2 (1), 52-65.

[42] Laouris, Y. \& Eteokleous, N. (2005). We need an educationally relevant definition of mobile learning. Proc. 4th World Conference on Mobile Learning, mLearn 2005, Oct 25 - 28, Cape Town, South Africa.

[43] Laufer, B. (1998). The development of passive and active vocabulary in a second language: Same or different? Applied Linguistics, 12, 255-71.

[44] Laufer, B, Hulstijn J.H. (2001). Incidental vocabulary acquisition in a second language: The construct of task-induced involvement. Applied Linguistics, 22,1-26.

[45] Laufer, B. \& Goldstein, Z. (2004). Testing vocabulary knowledge: Size, strength, and computer adaptiveness. Language Learning, 54, 469-523.

[46] Laufer, B., Elder, C., Hill, K. Congdon P. (2004). Size and strength: Do we need both to measure vocabulary knowledge? Language Testing, 21,202-26.

[47] Levy, M., \& Kennedy, C. (2005). Learning Italian via mobile SMS. In A. Kukulska-Hulme \& J. Traxler (Eds.), Mobile Learning: A Handbook for Educators and Trainers. London: Taylor and Francis.

[48] Levy, M., \& Kennedy, C. (2008). L'italiano al telefonino: Using SMS to support beginners' language learning. ReCALL, 20 (3), 315-330.

[49] Lu, M. (2008). Effectiveness of vocabulary learning via mobile phone. Journal of Computer Assisted Learning, 24(6), 515-525.

[50] McNicol, T. (2004). Language learning on the move. Japan Media Review. Retrieved June 25, 2005, from http://ojr.org/japan/wireless/1080854640.php

[51] Melton, A. W. (1970). The situation with respect to the spacing of repetitions and memory. Journal of Verbal Learning and Verbal Behavior, 9, 596-606.

[52] Mostakhdemin-Hosseini, A. and Tuimala, J. (2005). Mobile Learning Framework. Proceedings IADIS International Conference Mobile Learning 2005, Malta, pp 203-207.

[53] Nah, K. C. (2008). Language learning through mobile phones: Design and trial of a wireless application protocol (WAP) site model for learning EFL listening skills in Korea. Unpublished Doctoral Dissertation. The University of Queensland, Brisbane, Australia.

[54] Nah, K.C. White, P. \& Sussex, R. (2008). The potential of using a mobile phone to access the Internet for learning EFL listening skills within a Korean context. ReCALL 20 (3), 331-347.

[55] Naismith, L., Lonsdale, P., Vavoula, G. and Sharples, M. (2004). Literature Review in Mobile Technologies and Learning. Futurelab. http:// www. futurelab. org.uk/resources/ publications_reports_articles/literature_reviews/Literature_Review203.

[56] Nakata, T. (2008) English vocabulary learning with word lists, word cards and computers: implications from cognitive psychology research for optimal spaced learning. ReCALL, 20(1), 2-30.

[57] Nation, I.S.P. (1990). Teaching and learning vocabulary. Newbury House, New York.

[58] Nation, I.S.P. (2001). Learning vocabulary in another language. Cambridge: Cambridge University Press.

[59] Nation, I.S.P. \& Meara, P. (2002). 'Vocabulary' in Schmitt, N. (Eds.): An Introduction to Applied Linguistics. London: Arnold.

[60] Norbrook, H., \& Scott, P. (2003). Motivation in mobile modern foreign language learning. In J. Attewell, G. Da Bormida, M. Sharples, \& C. Savill-Smith (Eds.), MLEARN 2003: Learning with mobile devices (pp.50-51). London: Learning and Skills Development Agency. Retrieved June 20, 2005, from http://www.lsda.org.uk/files/pdf/1421.pdf

[61] O’Malley, C., Vavoula, G., Glew, J., Taylor, J., Sharples, M. and Lefrere, P. (2003). Guidelines for learning/teaching/tutoring in a mobile environment. Mobilearn project deliverable. http://www.mobilearn.org/download/results/guidelines.pdf

[62] Pettit, J. \& Kukulska-Hulme, A. (2007). Going with the Grain: Mobile Devices in Practice. Australasian Journal of Educational Technology, (AJET), 23 (1), 17-33.

[63] Pecherzewska, A, \& Knot, S. (2007). Review of existing EU Projects Dedicated to Dyslexia, Gaming in Education and Mlearning. WR08 Report to CallDysc project.

[64] Piaget, J. (1970). Science of education and the psychology of the child. New York: Orion Press.

[65] Robinson, P. (2005). Cognitive abilities, chunk-strength, and frequency effects in implicit artificial grammar and incidental L2 learning: Replications of Reber Walkenfeld \&Hernstast (1991), and Knowlton \& Squire (1996) and relevance for SLA. SSLA, 27, 235-268.

[66] Roschelle, J. (2003). Unlocking the learning value of wireless mobile devices. Journal of Computer Assisted Learning, 19 (3), 260-272.

[67] Roschelle J., Sharples M. \& Chan T.W. (2005). Introduction to the special issue on wireless and mobile technologies in education. Journal of Computer Assisted Learning 21, 159-161.

[68] Russo, N., Mammarella, N., Avons, S.E.(2002). Toward a unified account of spacing effects in explicit cued-memory tasks. Journal of Experimental Psychology, Learning, Memory, and Cognition, 28 (5), 819-829.

[69] Salaberry, M.R. (2001). The use of technology for second language learning and teaching: A retrospective. The Modern Language Journal, 85, 39-56.

[70] Savill-Smith, C. and Kent, P. (2003). The use of palmtop computers for learning: A review of the literature. London: Learning and Skills Development Agency.

[71] Schmidt, R. (1994). Implicit learning and the cognitive unconscious: Of artificial grammars and SLA. In N. C. Ellis (Ed.), Implicit and explicit learning of languages (pp. 165-210). London: Academic Press.

[72] Seabrook, R., Brown, G. D.A, \& Solity, J.E. (2005). Distributed and massed Practice: from laboratory to classroom. Applied Cognitive Psychology, 19, 107-122. 
[73] Serrano, R. \& Munoz, C. (2007). Same hours, different time distribution: Any difference in EFL? System 35, $305-321$.

[74] Shahrzad, A. \& Derakhshan, A. (2011). The Effect of Instruction in Deriving Word Meaning on Incidental Vocabulary Learning in EFL Context. World Journal of English Language, 1(1), 68-79.

[75] Sharples, M., Taylor, J. and Valvoula, G. (2005). Towards a theory of mobile learning. mLearn 2005. Cape Town, South Africa, http://www.mlearn.org.za/CD/papers/Sharples-\% 20Theory\%20of\%20Mobile.pdf

[76] Sharples, M. (2006). Big Issues in Mobile Learning: Report of a workshop by the Kaleidoscope Network of Excellence Mobile Learning Initiative. LSRI, University of Nottingham, UK.

[77] Simina,V. and Hamel, M-J. (2005). CASLA through a social constructivist perspective: WebQuest in project-driven language learning. ReCALL, 17(2), 217-228.

[78] Song, Y. \& Fox, R. (2008). Using PDA for undergraduate student incidental vocabulary testing. ReCALL 20 (3), $290-314$.

[79] Stead, G. (2005). Moving mobile into the mainstream. In: ASCILITE 2005 Conference: Balance, Fidelity, Mobility: maintaining the momentum? Conference Proceedings, http://www.ascilite.org.au/conferences/brisbane05/blogs/proceedings/53_Stead. pdf

[80] Stockwell, G. (2007). Vocabulary on the move: Investigating an intelligent mobile phone-based vocabulary tutor. Computer Assisted Language Learning, 20(4), 365-383.

[81] Stockwell, G. (2008). Investigating learner preparedness for and usage patterns of mobile learning. ReCALL, 20(3), 253-270.

[82] Thornton, P. \& Houser, C. (2002). Using mobile web and video phones in English language teaching: Projects with Japanese College Students. In Directions in CALL: Experience, Experiments \& Evaluation (Eds. B. Morrison, C. Green \& G. Motteram), (pp. 207-224). English Language Centre, Hong Kong Polytechnic University, Hong Kong.

[83] Thornton, P. \& Houser, C. (2003). Using mobile phones in Education. Proceedings of the Second International Workshop on Wireless and Mobile Technologies in Education, pp. 3-10. IEEE Computer Society, Jungli, Taiwan.

[84] Thornton, P. \& Houser, C. (2005). Using mobile phones in English education in Japan. Journal of Computer Assisted Learning, $21,217-228$.

[85] Toppino, T.C., Bloom, L.C. (2002). The spacing effect, free recall, and two-process theory: a closer look. Journal of Experimental Psychology: Learning, Memory and Cognition, 28 (3), 437-444.

[86] Traxler, J. (2005). Defining mobile learning. Proceedings IADIS International Conference Mobile Learning, Malta, 261-266.

[87] Traxler, J. (2007). Defining, discussing, and evaluating mobile learning: The moving finger writes and having written. International Review of Research in Open and Distance Learning, 8(2),1-12.

[88] Trifanova, A., Knapp, J., Ronchetti, M., \& Gamper, J. (2004). Mobile ELDIT: Challenges in the transitions from an e-learning to an m-learning system. Trento, Italy: University of Trento. Retrieved July 24, 2005, from http://eprints.biblio.unitn.it/archive/00000532/01/paper4911.pdf

[89] Vavoula, G. N. and Sharples, M. (2002). KLeOS: a personal, mobile, knowledge and learning organisation system. Proceedings of the IEEE International Workshop on Wireless and Mobile Technologies in Education (WMTE '02). Vaxjo, Sweden: IEEE Computer Society, 152-156.

[90] Vygotsky, L. S. (1978). Mind in society: the development of higher psychological processes.Edited Cambridge Mass, London: Harvard University Press.

[91] Wang, S. and Higgins, M. (2006). Limitations of mobile phone learning.CALL Journal,2(1), 3-14.

[92] Winters, N. (2006). What is mobile learning? In: Sharples, M. (Eds.), Big Issues in Mobile Learning. Report of a workshop by the Kaleidoscope Network of Excellence Mobile Learning Initiative. Nottingham: University of Nottingham.

[93] Wood, K. (2003). Introduction to mobile learning (M learning) http://ferl.becta.org.uk/display.cfm?page $=65 \&$ catid=192\&resid=5194\&printable $=1$

[94] Wozniak P.A. (1995). Economics of learning. Doctoral dissertation, University of Economics, Wroclaw, Poland.

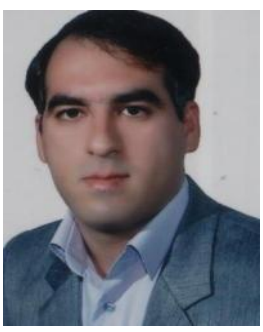

Ali Derakhshan is currently a $\mathrm{PhD}$ candidate majoring in TEFL at Allameh Tabataba'i University (ATU), Tehran, Iran. He received his M.A. in TEFL from University of Tehran, Iran in 2009. He has been a visiting lecturer at Sharif University of Technology and Allameh Tabataba'i University (ATU). He was also awarded the best national teacher in two consecutive years. He has coauthored some books and published some articles in international journals. His research interests are Language Assessment, Interlanguage Pragmatics Development \& Assessment, Syllabus Design, Teacher Education, Focus on Form/s, and MALL. Mr. Ali Derakhshan is the member of the Teaching English Language and Literature Society of Iran (TELLSI).

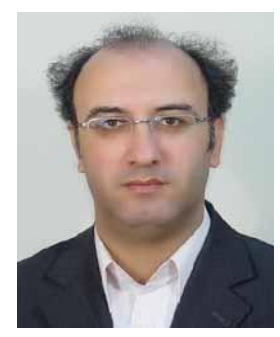

Hossein Khodabakhshzadeh was born in Torbat-e-Heidarieh in 1974 and revieved hie BA in TEFL from Islamic Azad University of Torbat-e-Heidarieh in 1997. He persued his education at Iran University of Science and Technology and obtained MA in TEFL. He s currently the PhD candidate in TEFL at Ferdowsi University of Mashad.

Serving as a faculty member of Islamic Azad University of Torbat-e-Heidarieh for over a decade, he has taught various courses in TEFL. He has been a Lecturer in Payam noor University of Mashad, Islamic Azad University of Mashad, and Tabaran University. He has been the Head of English department at Islamic Azad University for 3 years. He has also Supervised the Ayande sazan English Institute for more than 10 years and currently is the Supervisor of Hafez and Jahan Elm institutes. He has also had some other executive jobs at Islamic Azad University of Torbat-e-Heidarieh. His main areas of interest are mostly Language Assessment, Methodology in Language Teaching and Teacher Training. 